Article

\title{
Developmental Sustainability through Heritage Preservation: Two Chinese Case Studies
}

\author{
Xiao Song ${ }^{1}$, Kee-Cheok Cheong ${ }^{2}$, Qianyi Wang ${ }^{3}$ and Yurui $\mathrm{Li}^{4,5, *}$ \\ 1 Cultural Center Malaysia, University of Malaya, 50603 Kuala Lumpur, Malaysia; ellasongxiao@gmail.com \\ 2 Faculty of Economics and Administration, University of Malaya, 50603 Kuala Lumpur, Malaysia; \\ keecheok1@yahoo.com \\ 3 Economic School, Shandong Technology and Business University, Yantai 264000, China; \\ qianyiwang@sdtbu.edu.cn \\ 4 Institute of Geographic Sciences and Natural Resources Research, Chinese Academy of Sciences, \\ Beijing 100020, China \\ 5 Key Laboratory of Regional Sustainable Development Modeling, Chinese Academy of Sciences, \\ Beijing 100020, China \\ * Correspondence: liyr@igsnrr.ac.cn
}

Received: 20 March 2020; Accepted: 28 April 2020; Published: 3 May 2020

check for updates

\begin{abstract}
Cultural heritage is a vital part of a society's existence. This role has particular relevance for China, with arguably one of the largest stocks of cultural assets, tangible and intangible, in the world. Recognizing the tension between cultural preservation and economic development as a general context, this paper examines the specific additional challenges China faces in its rush towards economic development. In providing both generic and China-specific contexts, this paper has as its objective to understand how Chinese policy-makers, both central and local, attempt to resolve the contest between cultural preservation and economic development, specifically rural rejuvenation. Through two case studies - of Lijiang in Yunnan province and Rizhao in Shandong province-this paper shows contrasting strategies to leverage local intangible cultural assets. Comparing these strategies reveals both the advantages and challenges inherent in each. A successful strategy captures the benefits of cultural tourism while minimizing its costs.
\end{abstract}

Keywords: rural revitalization; rural tourism; heritage preservation

\section{Introduction: The Role of Cultural Heritage Preservation}

Cultural heritage, defined as "the legacy of physical artifacts and intangible attributes of society inherited from past generations" [1] has long had a legitimate claim to be a major, albeit non-material, dimension of human well-being because it embodies "all the shared products of a given society" [2,3]. UNESCO itself notes that "... heritage is a valuable factor for empowering local communities and enabling vulnerable groups to participate fully in social and cultural life." (https://en.unesco.org/ content/preserving-our-heritage). Thus, the original focus on monuments and material artifacts from Western civilizations has been greatly expanded to encompass cultural expressions in the form of objects as well as processes [4].

UNESCO's recognition, through its 2003 Convention for the Safeguarding of the Intangible Cultural Heritage (ICH), is particularly significant for Asia, where many traditions and practices are passed on from generation to generation verbally and through apprenticeships [5] (p. 21). It is of vital importance to China, with its huge inventory of cultural heritage assets from the country's millennia of history and vast geographical size. The large number and variety of experiences provide relevant lessons for situations in other countries and contexts. Considerable research exists on ICH in China [6-8] but there is no agreement on the success of China's efforts [9-11] in ICH preservation. 
This paper has as its primary objective to provide a coherent narrative of China's changing strategies to capture the benefits from leveraging intangible cultural heritage tourism. Under this overarching framework, case studies of specific strategies are examined in detail to facilitate comparisons of the benefits and challenges each strategy produces. This is also how this paper is structured. The next section sets the general discussion linking heritage protection with economic development. The China situation provides the specific country context. In Section 4, analysis is undertaken of the evolution of cultural heritage tourism with sustainability as a long-term goal. Section 5 describes the two case studies and their comparison. Section 6 concludes.

\section{Methodology}

In developing the narrative on the China experience, reliance has been placed on extant research, both generic research on ICH preservation and cultural tourism in a country-specific and cross-country context, and also specifically on policy studies on rural development in China. There has been an abundance of research, both generic and China-focused. The China context is important in that these strategies fit into rural development policies. These studies, employing a variety of methodologies, varying from sample surveys to secondary literature reviews, provide a coherent narrative of the evolution of policies and strategies. The analytical narrative that details the progressive sequencing of changes is laid out in Section 4.

A second qualitative approach is the use of the case studies method for two case studies at different stages of implementation. The advantages and drawbacks of the case study approach are well known. Even with its limitations with respect to generalisability [12], it remains a powerful tool for deeply probing the relationship between rural development and rural cultural preservation in specific contexts, drawing lessons from these case studies. Because of the relatively limited written resources for these cases, a number of interviews with key stakeholders of the dances have had to be conducted. This was especially true of Rizhao's Fishermen's dances, where public performances were temporarily prohibited during the Cultural Revolution years and were not revived until the 1980s, so that no records were kept. The methodology employed was akin to narrative policy analysis

\section{Study Context}

Cultural Heritage and Development. The product of a society through history, cultural heritage represents its record, both of success and failure, in development. Because it exists in a community's daily lives, it is as much a mirror of contemporary socio-economic development as of historical achievements, both of which are themselves foundations for the future [12]. Cultural heritage preservation is then seen as an economic development tool, with targeted areas, geographic dispersion, projects of varying sizes, and modernization as tangible benefits. Thus Rypkema (1999) noted that historical preservation is a vehicle of broader ends, with positive impacts that include job creation, job training, product differentiation, small business incubation and tourism opportunities [13]. Iossifova (2014) lists the benefits of developing cultural tourism as part of cultural heritage preservation and local economic development. These include creating new jobs, providing job training and contributing to local self-sufficiency by substituting imported with locally produced goods and achieving "appropriate modernisation [10] (p. 37)."

However, the relationship between cultural heritage and development is contested. First, globalization and its tendency for the standardization of products and services, coupled with industrialization and mass production, have worked against the creative arts and cultural heritage [14,15]. Second, many planners prefer modernity, which makes for a more attractive environment over heritage architecture, unmindful of the positives that the latter bring by, among others, opening up local economic opportunities through tourism services [16,17]. Third, many development interventions have prioritized "progress" over heritage preservation, exploited cultural heritage economically in the name of cultural capital, and implemented culturally disruptive development projects [18]. 
To these contestations, direct trade-offs between cultural preservation and economic development in the implementation of heritage preservation projects must be added. Non-tangible examples of trade-offs include: retaining traditional cultural practices vs. adaptation to modern times; professionalization vs. retention of traditional norms in areas such as management and finance, and commercialization (catering to what tourists want) vs. traditional practices (keeping to tradition) that may include the shift to a central location from traditional locations.

The extent to which heritage preservation is compatible with sustainable development has also been debated. This debate has pitted those [19], who refute arguments of the inevitability of conflict between heritage building preservation and sustainability, and others [20] who emphasized the common goal of managing limited resources among both preservation and sustainability movements, against those who argue that conflict between these objectives does exist, an example being heritage buildings being major consumers of energy and generators of greenhouse gases [1]. Such conflicts may exist partly because policies may only focus selectively on economic sustainability, or partly because of implementation issues [21].

Given these conflicts, it is hardly surprising that conflict theories have been widely applied to analyse endeavours leveraging cultural heritage for development, the most common of which is tourism. Yet, as McKercher, Ho and Du Cros [22] show, there is no inevitability to this conflict, with different models applicable within a broad conceptual framework. Nevertheless, the potential for goal conflict is compounded in the China historical, political and social contexts, with its huge and diverse stock of cultural heritage, both tangible and intangible, that defy the best efforts of government to manage (next Section).

The China Context of Cultural Heritage Protection. China is arguably one of the richest repositories of cultural heritage, spanning millennia of Chinese civilization, history and cultural traditions. In addition, through thousands of years of historic interactions with neighbouring areas and other parts of the world, China has also played an important part in the cultural heritage of these territories [23] (p. 70).

China's history of heritage conservation was said to date from the 1930s [24] (Wang, 2008). Despite this, only a fraction of historical heritage sites had been recorded, with many others lost to posterity [25]. In 1982, shortly after liberalization in 1978, China passed the Law on the Protection of Cultural Relics, which established a conservation system, and a list defining "famous cities of historical and cultural value". In 1986, a second group of famous cities was added to the first. In 2002, the 1982 Law was revised to define historic areas as "small towns, neighborhoods with an unusual wealth of cultural relics of important historical value or high revolutionary memorial significance". This would be the precursor of the 2003 UNESCO International Convention for the Safeguard of the Intangible Cultural Heritage of which China was a signatory. In 2005, the State Council issued the Circular on Strengthening the Conservation of Cultural Heritage, which distinguished between tangible and intangible cultural heritage for the first time. Following the Circular, in 2006 and 2008, the first two groups of national ICH were listed and published. More recently, the government maintained its focus on the country's ICH by adding three traditional holidays—tomb-sweeping day, dragon-boat day, and mid-autumn day-as public holidays.

Despite this recognition through legislation, there exist legislative deficiencies [26] and inadequate attention at the sub-national levels, which are given to viewing cultural heritage as an integral part of development, and thinking even less of sustainable development [27] (Petronela, 2015). Shen and Chen (2010) attributed the destruction of many heritage sites to the country's rapid transformation: "Resumption of private ownership, market exchange, urban development, labor mobilization, and booming tourism all became new human threats that endangered sites and objects ... " [25] (p.75). This inadequate attention, mostly through ignorance of heritage management, and consequently of resources has seen "China (losing) some 70 percent of its historic cities and an estimated 44,000 ancient ruins, temples and other cultural sites over the last twenty years" [10] (p.10). Despite the Central 
Government's efforts, local interest in the implementation of cultural heritage has been limited, and sporadic and financial and human resources scarce.

These challenges are balanced by several significant positives. Among the latter are: (1) the launch of the Third National Heritage Site Inventory that increased the number of registered immovable cultural properties to 760,000 and that of state priority protected sites to 4296; (2) significant improvements in a large number of these sites; (3) conservation campaigns at national capital construction sites; (4) systematic listing and management of Chinese sites on the World Heritage List; (5) theory development about cultural heritage conservation and identification of new types of cultural heritage; and (6) the annual organization of the Wuxi Forum on the Conservation of China's Cultural Heritage [28]. China has also set up an Intangible Cultural Heritage Protection Network, comprising nearly 2500 institutions with over 17,000 personnel as at the end of 2018 [29].

Even as these efforts were ongoing, a new strategy has been conceived that connects rural rejuvenation with cultural heritage-based tourism. China's new approach to rural development represents an attempt to slow, if not reverse, the rural-urban migration flow and to see rural development resume its original role as a growth driver for China's economy, a role long sacrificed for urban development [30] (Zhuang, 2019). How well the objectives of cultural heritage-based tourism align with those of rural development is briefly sketched out in the next section.

\section{Analysis: Cultural Heritage Protection through Rural Rejuvenation}

China's rural development experience is arguably unique (Table 1). Lewis' (1954) model [31], which explains the transition from a subsistence to a capitalist economy that is often cited to explain the inevitability of rural to urban migration in developing economies, is not supported empirically in China [32-35]. Chinese data for 1990-2013 reveal an urban-rural income gap that has an inverse U shape. A widening gap between rural and urban area incomes persisted until the mid-2000s, followed by a reverse trend thereafter, suggesting the closing of the urban-rural disparity.

Table 1. Timeline of China's Rural Development and Cultural Heritage Protection.

\begin{tabular}{lll}
\hline Time Period & \multicolumn{1}{c}{ Policies } & \multicolumn{1}{c}{ Impact } \\
\hline \multirow{2}{*}{$1978-2005$} & $\begin{array}{l}\text { Surplus agricultural labor from economic } \\
\text { liberalization fuelled rural-urban migration, } \\
\text { but restrained by township and village } \\
\text { enterprises (TVE) growth, household } \\
\text { registration system }\end{array}$ & $\begin{array}{l}\text { Income disparities, rural-urban migration, } \\
\text { but Lewis model not fully applicable }\end{array}$ \\
\hline \multirow{2}{*}{1990 s to 2006 } & $\begin{array}{l}\text { 1990s reclassification from rural to urban: no } \\
\text { migration. However, rural property restrictions, } \\
\text { tax reforms increased pressure on migration }\end{array}$ & "Vacant rural residence phenomenon" \\
\hline 2006 & $\begin{array}{l}\text { Policy of increasing urban land and reducing } \\
\text { rural residential land: "new rural construction" }\end{array}$ & $\begin{array}{l}\text { Mixed success, top-down, failed to take into } \\
\text { account rural residents' views }\end{array}$ \\
\hline \multirow{2}{*}{2014} & $\begin{array}{l}\text { "People-oriented approach", or "new } \\
\text { urbanization" }\end{array}$ & $\begin{array}{l}\text { Bottom-up approach more acceptable to } \\
\text { rural residents }\end{array}$ \\
\hline & $\begin{array}{l}\text { "Rural socialization" integrates rural and urban } \\
\text { stakeholders, consistent with "rural } \\
\text { rejuvenation" strategy }\end{array}$ & $\begin{array}{l}\text { Rise of "cultural-oriented rural } \\
\text { development", leading to heritage tourism. }\end{array}$ \\
\hline
\end{tabular}

The widening gap early on resulted from China's early transition economy reforms. Even before liberalization, a household registration system (HRS) was put in place in China, causing severe rural and urban social-spatial disparities that lasted decades [36,37]. Under the HRS, rural residents could not enjoy the social welfare benefits available to urban residents and population movement was restricted. After liberalization reform, rapid urbanization eroded the efficacy of the HRS. To absorb surplus labor released by agricultural liberalization, the central government promoted the establishment of township and village enterprises in the 1980s that allowed rural residents to be reclassified as urban without 
physically moving to cities ("Move to town rather than City (Jincheng bu jincun))". For a while, this eased the pressure of rural-urban migration, but the measure was criticized for just stemming the urban flow rather than developing rural areas [38,39]. In the early 1990s, the heightened pace of urbanization forced local governments to create administratively new urban areas through the amalgamation of towns and counties. Statistics showed that 64 counties were reclassified as cities between 1986 and 1988 [40].

While the above developments would seem to vindicate Lewis's theory, rural property restrictions imposed by China's central government actually inhibited rural-urban migration. All land in China belongs to the state; however, whereas urban land could be traded in the open market, while rural land could not. The result was migrants from rural areas leaving their rural homes unoccupied, creating "Vacant Villages" (Kongxin Cun). To make things worse, decentralization and tax reform in 1994 rendered urban land leasing a major income source [41-43].

Given this undesirable state of affairs, a new phase integrating rural and urban development began when the central government put forward the "increasing urban land and decreasing rural residential land" policy in 2006 to demolish rural vacant houses and consolidate rural land use. The freed-up land could then be traded in the land market and used for urban development. Dubbed "new rural construction", the focus was on urbanization, with land the policy instrument and the approach "top-down". Local governments seized this opportunity to acquire rural land, relocating rural residents into high-rise apartments without regard for their willingness [41-43].

Despite some successes, variations in local conditions and differences in government capabilities and involvement meant that the above approach encountered only mixed success. Taking account of local conditions ushered in rural development reform that came, since 2014, to be known as "New Urbanization". This new approach aimed to urbanize China through a more "people-oriented approach", correcting the errors of the earlier "land-oriented approach" [44]. This represented a breakthrough in terms of its bottom-up policy-making based on local stakeholders' preference [45], and was to provide the conceptual framework for the current comprehensive approach of "Rural Rejuvenation" centered on "people development" [46].

Clearly, while national policies such as "City supporting rural village", and "Industry financing agriculture", have all promoted rural development that, together with national economic growth, diminished China's rural-urban disparities since the mid-2000s [47], China's experience with rural in situ development had also run counter to Lewis's theory since 1978, primarily because conditions in rural China were materially different from those in a "typical" developing economy. Thus, China's rural income in megacities was not dominated by agricultural activities but by operating income (shareholder dividends from collective enterprise), land-leasing rents, and wages from urban activities [48-52]. Meanwhile, rural peasants enjoy rural life, and refuse to relocate to urban areas, many choosing to commute between rural and urban areas [53-55]. Further, some rural households were able to develop private businesses in villages [56-58]. These factors enabled in situ rural development to achieve a degree of success [59-61].

Consonant with "people-oriented rural development", Yan Chen \& Xia (2018) advanced their Rural Socialization Theory, which asserted that China's rural regeneration requires not only the engagement of local stakeholders (local grassroots, local government), but also the participation of local counterparts [62]. This theory posits that China's expanding middle class, characterized by high income and education and accounting for $37.4 \%$ of the total population, requires personalized consumption that can be met partially by rural activities. For instance, urban environmental pollution renders vacations and holiday residences in rural locations attractive for the urban middle class, thus, giving impetus to rural rejuvenation [63-65]. Rural socialization also entails agriculture industrialization and economic sector integration, synthesizing primary, secondary and tertiary sectors.

Rural socialization, through its engagement of both rural and urban stakeholders, allows rural residents to trade land contract right and operating right (Sanquan Fenzhi) in the markets, thus attracting urban capital into rural areas and promoting urban-rural integration [66-68]. With urban capital, rural 
agro-industrialization can occur through consolidating fragmented farmland and commercializing rural land. Rural residents who hold land rights become enterprise shareholders, and are able to diversify and increase their incomes. There is therefore integrated development of urban and rural areas, ensuring that rural development fulfils both local and urban needs.

The benefits of this approach notwithstanding, the challenges are many. This approach has been criticized for its heavy fiscal burden on local governments, since rural migrants now enjoy rights accorded to urban residents [69]. Rural revitalization can also be confronted with its historical legacy of neglect and primacy accorded to urban areas) [33,45]. Cheap land or tax privileges may also attract enterprises with heavy pollution, affecting the local environment and future development. Finally, urban renewal often sees the demolition of old buildings, and cultural heritage sites can be lost through this process [70].

An important consequence of this approach is the emergence of cultural-oriented rural development as a tertiary sector activity. Empirical research shows rural residents benefiting economically by diversifying their income sources, with rural areas adopting tourism to boost their rural economies [33,71-73]. In keeping residents gainfully employed, heritage tourism allows local residents to diversify their incomes, retain rural residents and ease the urbanization pressure. Meanwhile, through training in these cultural activities, talents are developed that can form the backbone of the tertiary sector. This mode of rural development can be classified as (1) people-oriented rural development aiming to attract urban tourists through commercializing a culturally specific, ethnic and/or rural ethnic lifestyle; (2) geography-oriented rural development, which attracts tourism with the possession of natural or geographical landscapes; and (3) agro-based rural development, that promotes tourism through "back to the land" farming activities.

This is in addition to the socio-cultural benefits of heritage protection, which make for a sense of identity and cohesion within the community, while simultaneously ensuring the preservation of its cultural heritage. It is also a good fit for "people-oriented rural development" that requires local stakeholders' participation to reshape the rural economy based on local characteristics. To the extent that this form of tourism does not rely on the possession of physical assets or endowments, it can be applied to hilly or poor agricultural terrains and small urban centers that lack the agglomeration advantages large urban conurbations possess. The timing of this strategy is also opportune, given China's enthusiastic response to UNESCO's prestigious "Masterpieces of the Oral and Intangible Heritage of Humanity", which not only raised consciousness but also provoked tremendous domestic pride [74].

\section{Empirical Analaysis: Pairing Tourism with Intangible Cultural Heritage Protection-Two Case Studies}

Tourism is often paired with cultural heritage preservation, with the former contributing to financially sustainable tourism policies, benefiting communities and developing virtual traveller communities [75]. Case studies also underline this relationship [76,77].

Although case studies are famously known to lack generalizability, and China's circumstances may not be easily replicable in other countries, there exist generic lessons from which other cases can be drawn. One is potential contestation between heritage preservation and sustainability. Another is local vs. state ownership. Yet another is achieving a balance between the costs and benefits of cultural tourism, all of which affect such projects to some degree. Tourism's role has become particularly important, as China attempts to include its use as a strategy for the country's rural rejuvenation, leveraging the abundance of intangible and tangible cultural heritage assets. While other countries may not stress suc ah linkage, they may well have linkages with other policies.

In this section, two cases (Figure 1) are examined. Lijiang, located in middle-east China in one, representing the successful use of tourism as an instrument for heritage preservation and income generation, and Rizhao, the coastal city in northeast China at a crossroads as it seeks to leverage and preserve its cultural heritage assets for posterity, are discussed. 


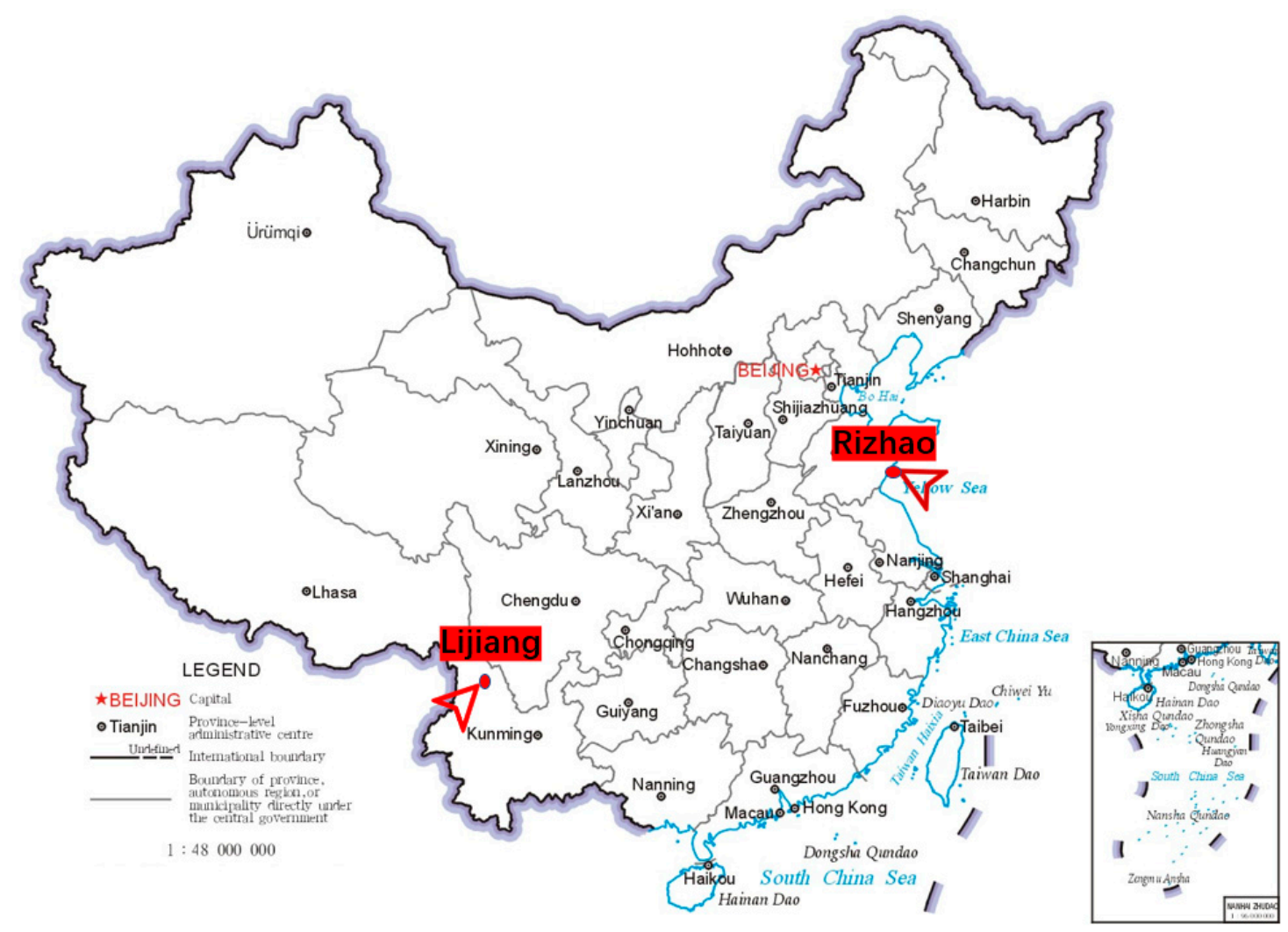

Figure 1. The geographical location of two case areas. Source: Obtained from http://bzdt.ch.mnr.gov. $\mathrm{cn} /$ index.html.

\subsection{Case Study 1: Successful Commercialization—Lijiang}

Lijiang, in the northwest of Yunnan province, China, is a well-known historical city, dating back to the Song Dynasty. With its ethnic diversity, local customs, handicrafts, scenic town streets, and riverine location with water from a stream flowing through the streets, Lijiang has leveraged its scenic setting to boost tourism, further fueled by its intangible cultural heritage-local dance.

The "Impression Lijiang" is a live dance performance directed by renowned film director Zhang Yimou, entailing an investment of RMB250 million, that portrayed the Dongba ethnic culture (Figure 2). Using the Yulong Mountain as the background, the dance is performed by 500 rural peasants from 16 Yunnan villages [78]. The dance's attraction to tourists lies in its spectacular staging of the minority's ethnic culture and history in a natural setting.

Launched in May, 2005, with performances beginning in July, 2006, and tickets at RMB 190, the performance has since been a major source of income for Lijiang. In 2015, the Annual Report of the Lijiang Yulong Tourism Co. Ltd., Lijiang's tourism management company, reported ticket sales of RMB219 million alone, with additional revenues from hospitality at RMB 96 million, ropeway walking tours at RMB414 million, and from other services at RMB57 million. In the next few years, it triggered related activities in rural areas that, while generating incomes locally, resulted in income from the Impression Lijiang performance falling dramatically from RMB 254 million in 2014 to RMB 98 million in 2018. Overall, however, it is a great innovation in rural development, allowing the diversification of rural incomes resources and increasing rural incomes greatly, boosting the local hospitality and restaurant sectors, and contributing to rural regeneration.

The Impression Lijiang performance created a commercial environment that inspired rural innovation in the surrounding areas. Thus, it attracted exogenous social capital input into developing the area, attracted urban tourists and investment, and mobilized local residents to respond to these external stimuli. It also spawned an innovative rural development strategy that takes advantage of a commercial environment. As a concrete example, sensing tourists' interest in the "Tea-Horse 
Road" passing through the city and performing in the "Impression Lijiang" gala, local rural peasants in Hai Village voluntarily organized the Hai Village Tourism Cooperative, developing a tourism program for tourists to experience the ancient transportation mode. As of 2008, 140 out of the 160 rural households have joined the cooperative. The average number of horses per household reached three in 2008. By investing in horses in the cooperative, the households receive dividends from the cooperative [79]. The success of this cooperative caused surrounding villages to follow suit and established more than 10 cooperatives, thus shifting the rural development model from being agro-based to cultural-oriented village-based.

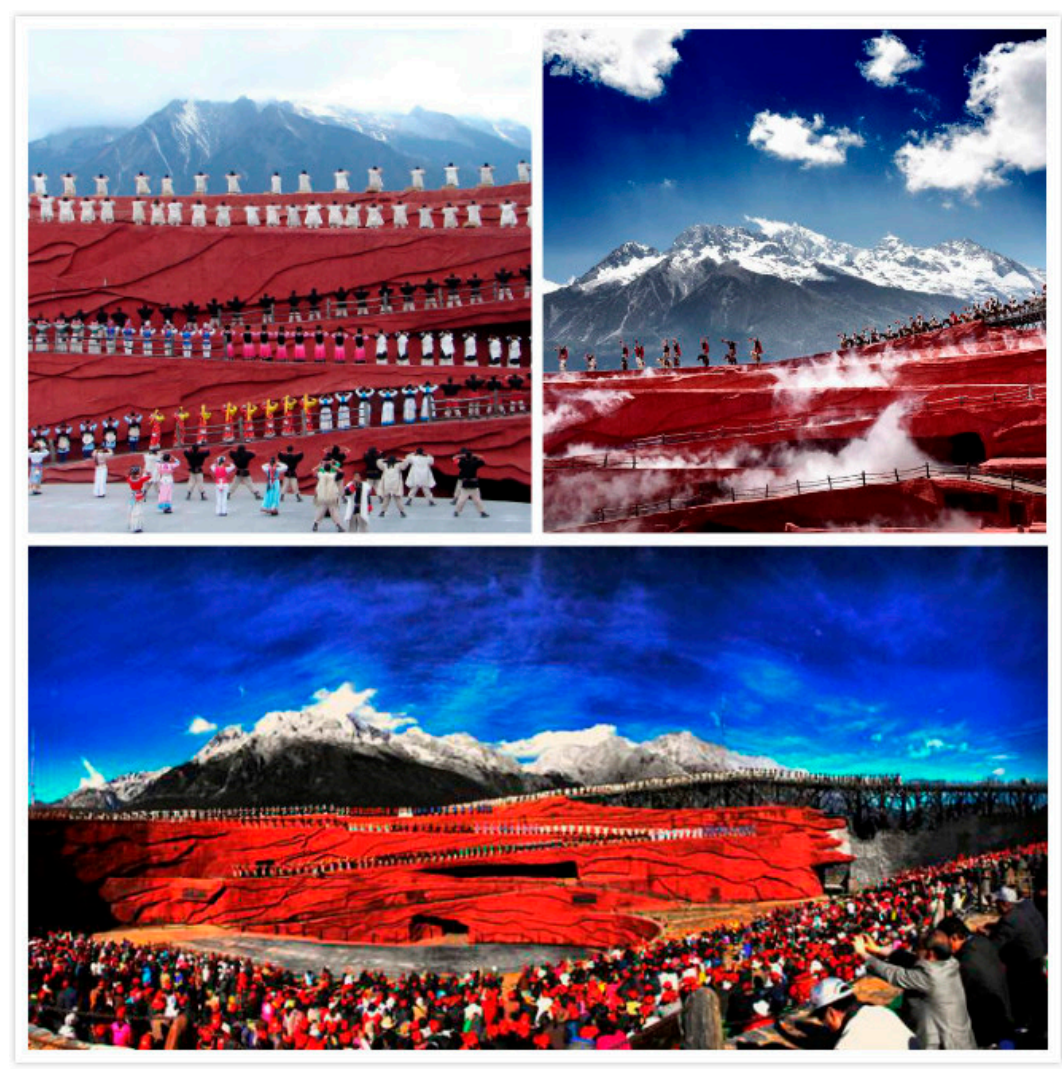

Figure 2. Impression Lijiang Dance Performance. Source: pictures collected from http://dp.pconline. com.cn/dphoto/2218513.html.

Meanwhile, rural incomes in the area rose dramatically while diversification also occurred, inspired by the single event. In 2004, Hai village's annual household income average was RMB 2000, which rocketed to RMB 48,000 in 2007 and further to RMB 67,000 in 2008. This income surpassed that of its urban counterparts, which was RMB 40,000 in 2007 [79]. This contributed to rebalancing the rural-urban disparity. In contrast to the more conventional agricultural-oriented rural development mode, which pursues intensive land-use and scale economy through encouraging rural dwellers to invest in agricultural cooperatives or companies, the Lijiang model exemplifies another method of rural revival, especially for those locations with scarce land resources. For this model, how to translate intangible cultural heritage into tangible activities is vital to success.

Improving rural living conditions is the logical consequence of the rise in household incomes. Since the "New Rural Construction Scheme" proclaimed during President Hu Jintao's era, China was attempting unsuccessfully to bridge the urban-rural gap through modifying rural living conditions $[80,81]$. The case of Lijiang shows how attention to cultural activities indirectly changed the physical environment of rural residents. With the diversified incomes from cultural activities, rural dwellers were able to refurbish their houses to purse a better life. Some rural residents turned their 
houses into home-stay hotels furnished with local flavour to emulate the style made popular in the "Impression Lijiang" performance (Figure 3).

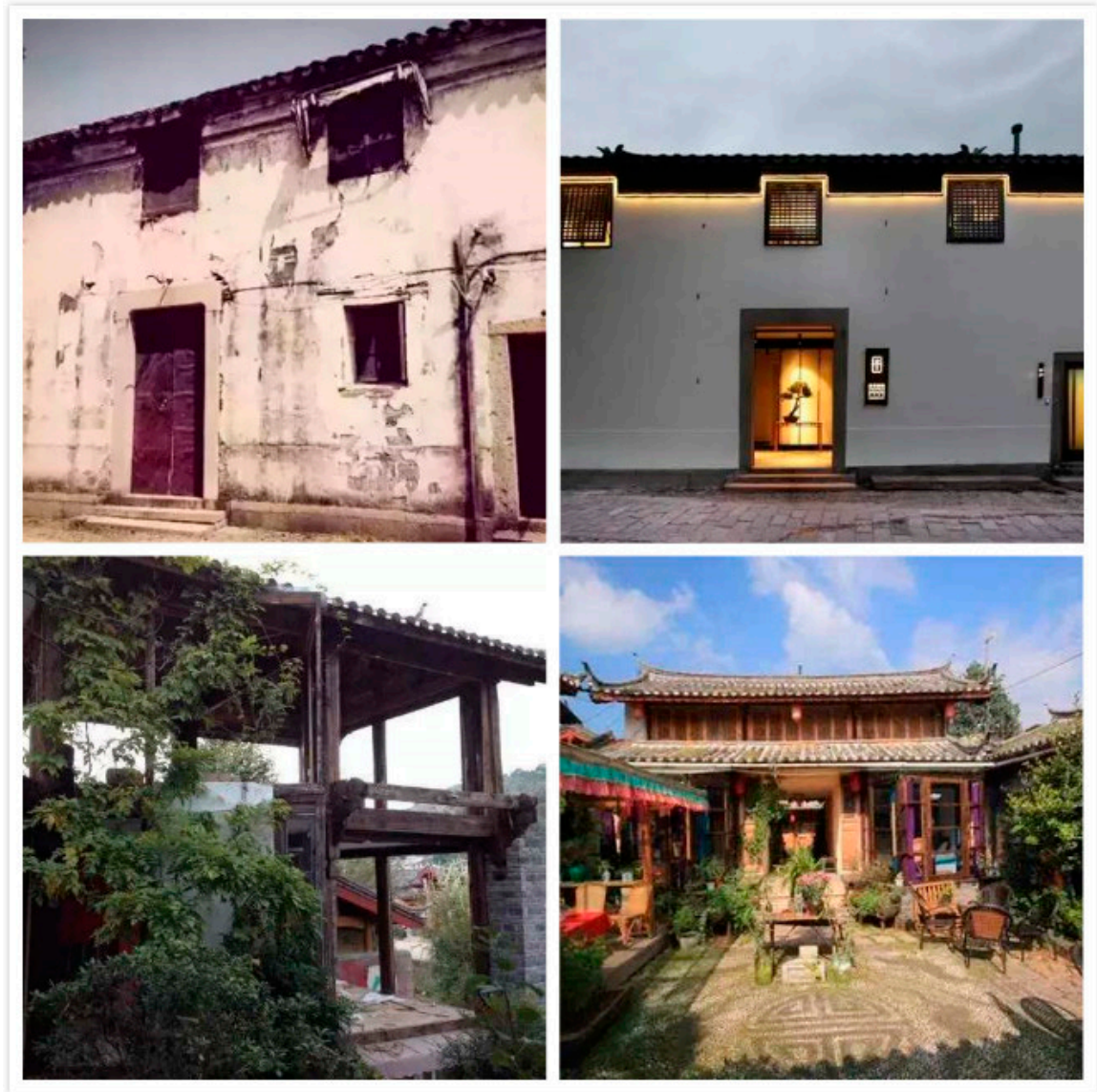

Figure 3. Refurbishing Old Rural Houses in Lijiang. Source: the pictures are collection from '100 rural house refurnishing cases', retrieved from http://www.360doc.com/content/16/0819/17/33281137_ 584378177.shtml.

Note: The picture shows two rural houses in Lijiang refurnishing process. The left two pictures depict the old image of the houses, while the refurnished houses are in the right column.

The performance helped reshape the rural community structure and build the credit system among rural community members. This is because the performance requires cooperation among all 500 participants. In addition, its related activities need the demutualization of resources they own. The establishment of the cooperatives is a reflection of demutualization, requiring a functional and systematic management and credit system. Among the scholars who argue for less government intervention in community management in more developed areas, such as having urban fringe villages or villages in downtowns shaping a "community of common destiny" [82], rural Lijiang is a good example. Demutualization and participation in the performance has helped to stem the flow of rural-urban migration and drive the community to function as a company to make bottom-up decisions themselves for the benefit of all members. It therefore fits into the 'people-oriented' concept of New Urbanization, with local stakeholders' participation. Bu and Chen, (2011) found villagers in Lijiang were more active in expressing their views on tourism development than before. Village affairs, such as road building and the formulation of village ethnic regulations that were decided by village cadres in the past, are now controlled by the villagers themselves [79].

At the same time, rural development raises awareness of local stakeholders in cultural preservation. Fast urbanization in the last decades was criticized for its side effects of destroying building heritage and diminishing local cultural value [83]. On the other hand, migrants to cities are keen on urban 
modernization and leaving their local traditions behind [70]. With these contrasting views, there is a danger that awareness of cultural heritage may gradually fade. However, Lijiang villagers themselves are now reshaping the community's cultural value and developing their history. They realize that cultural consciousness can sustain their communities. For instance, Naxi traditions and history helped to maintain their ethnic identity, the commercialization of which can create wealth. Therefore, dance competitions are frequently organized by villagers. Naxi cultural workshops and festivals are common events in rural Lijiang (Figure 4).

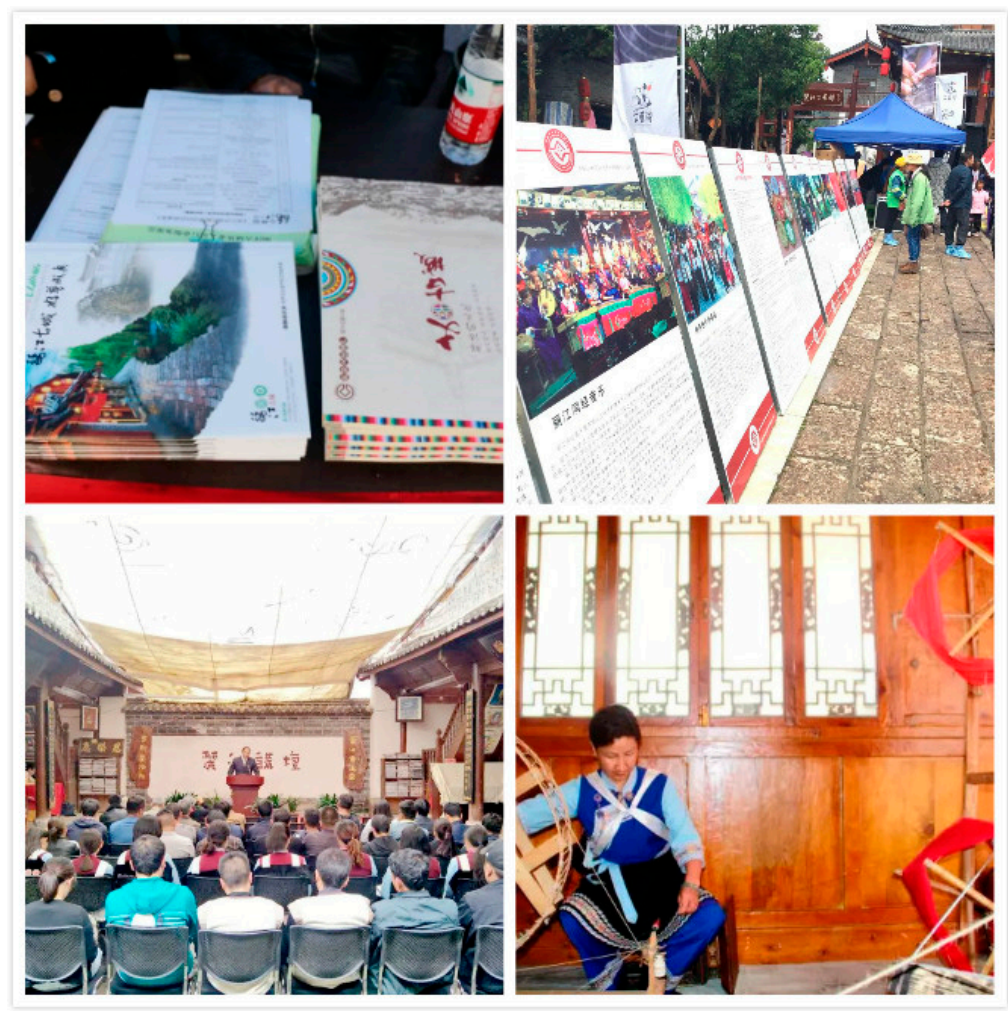

Figure 4. Lijiang Naxi Cultural Workshop in Rural Area. Source: pictures collected from Souhu news, retrieved from http://www.sohu.com/a/234944331_391640.

Lijiang's rural development has the advantage of preserving its rural environment and natural landscape. Both are part of traditional Naxi culture, illustrating the integration of people with nature. Rurality elements distinguish themselves from the urban, ensuring the sustainability of rural development in the long-run. For Lijiang, the basic concept behind rural-urban integration and cooperation is not assimilation but complementation. Perceiving this, director Zhang Yimou highlights in Lijiang Image the history, rurality and landscape in the Lijiang Image dance routines. For instance, leveraging on Yulong Mountain as background, the dance is performed by rural dwellers, expressing the human-environmental harmony and traditional rural activities (dance episode 1 and 4). Encouraged by the dance, more hotels in Lijiang are decorated by rural elements. The cooperatives in rural Lijiang provided the funding to maintain a clean environment and minimize environmental degradation caused by tourism activities.

\subsection{Case Study 2: At the Crossroads—Rizhao and Its Fishermen's Festival Dances}

Rizhao City with a current population of 3 million located in southern Shandong province facing South China possesses the topography, geomorphology, water resources, wind flow and other natural conditions to engage in maritime activities and this city is one of the biggest sea ports in East China. The maritime-based activities in Rizhao include deep sea fishing, import and export of fishing goods, and fish farming are the main sources of income in Rizhao. 
Rizhao is well-known for more than its maritime industry. Located in an area of great antiquity, Rizhao is rich in cultural assets, both tangible and intangible. Of the former, the best examples are the Longshan and Dongyi cultures, from which a wealth of historic artifacts has been unearthed. Of the latter, examples are the traditional sun-worship rituals which developed from these early cultures, as well as the rituals of the Fishermen's Festival, mainly the four dances, briefly described below (Figure 5). Its geographic location beside the sea, together with an abundance of sunshine, has made the city a major tourist destination, while its green credentials also make it a target for green tourism.

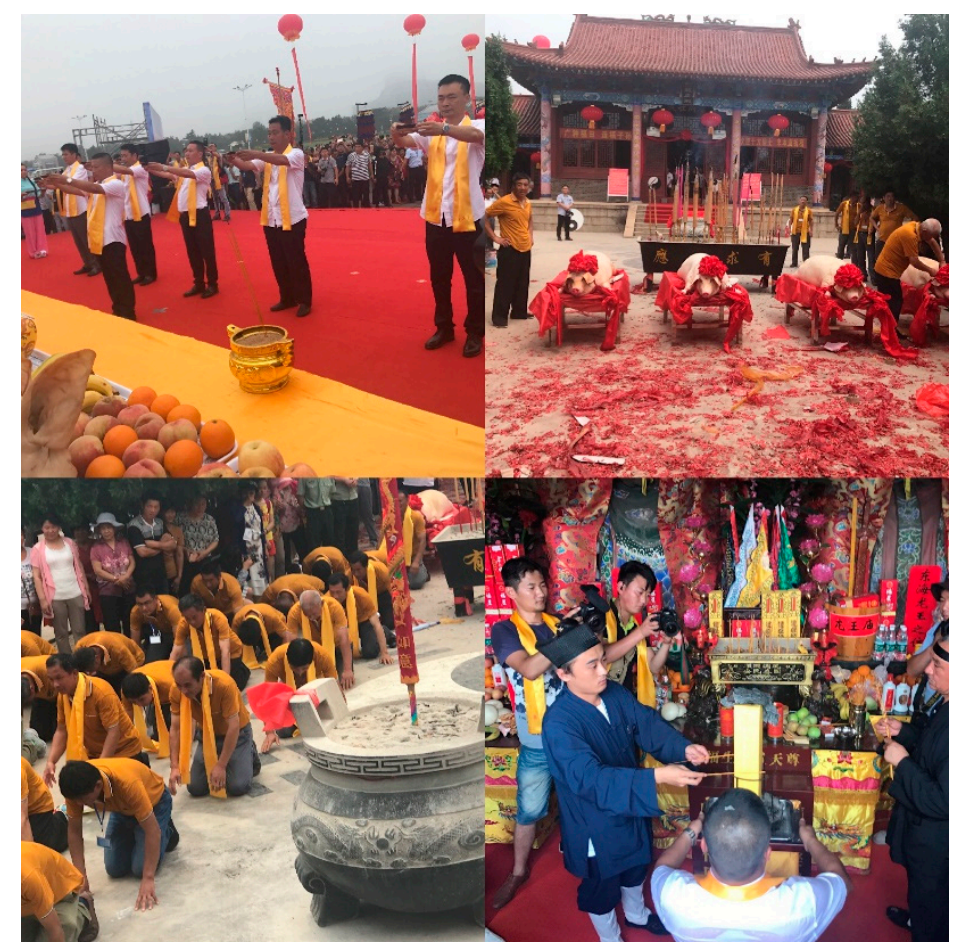

Figure 5. Festivals in Rizhao. Source: authors.

The Dances. The Fishermen's Festival in Rizhao is a celebration of fishing as a livelihood of the residents of Rizhao City since ancient times. The Festival's suite of four dances-the Dragon Dance, the Shui Dance, the Stilts Dance and the Han Boats Dance-is performed as unique worship ceremonies to honor the Sea Gods. These dances are described in Table 2 and photos of them are shown in Figure 6.

Table 2. Describing Rizhao's Fishermen's Dances.

\begin{tabular}{cc}
\hline The Dance & Description \\
\hline The Dragon Dance & $\begin{array}{r}\text { Origin unknown, but pre-Qing dynasty. Different versions all over China. } \\
\text { Worship of dragon as lord of all sea spirits. Pray for protection during fishing } \\
\text { and bountiful harvests. }\end{array}$ \\
\hline The Shui or Aquatic Dance & $\begin{array}{r}\text { Originated from Yuan dynasty. Prayer to appease sea spirits and creatures } \\
\text { under the Dragon King. Dancers don costumes mimicking the deities of } \\
\text { marine creatures. }\end{array}$ \\
\hline The Han Boats Dance & $\begin{array}{r}\text { Originated from Qing dynasty. Celebrates fishermen's life at sea and wish for } \\
\text { a comfortable life at home. Movements mimic work at sea }\end{array}$ \\
\hline The Stilts Dance & $\begin{array}{c}\text { Celebrates fishermen's use of stilts to move their nets to deeper waters. Often } \\
\text { celebrated ritually by combining it with the Hai Yang Yangge danceon land }\end{array}$ \\
\hline
\end{tabular}

Historical developments in China have shaped these practices and traditions, the Festival itself having undergone changes that affected the rituals and stature. The Festival today owes its revival to 
China's economic liberalization in 1978, this revival coinciding with the increased attention paid to the country's intangible cultural assets by the state. Since 2005, the annual Chinese Cultural Heritage Day has been held by the Rizhao Municipal Government. The Fishermen's Festival was introduced as a Provincial Intangible Cultural Heritage by the Shandong Provincial Government in 2007 and a National Intangible Cultural Heritage by the Central Chinese Government in 2008. In a nod towards potential tourism, China's State Council also fixed the date of the Fisherman Festival to fall on the 13th, June of the lunar calendar of every year.

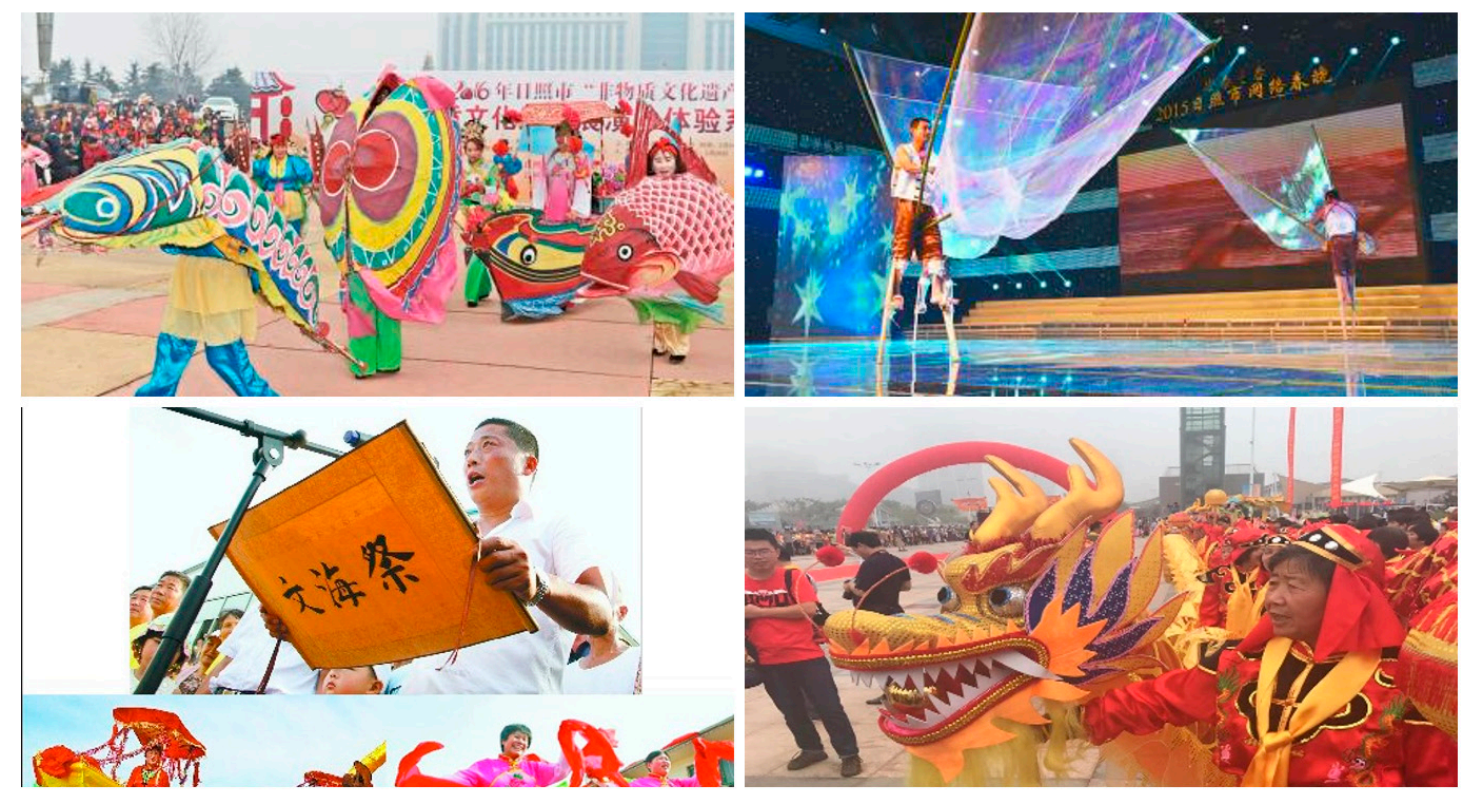

Figure 6. Dances of the Fishermen's Festival. Source: The pictures from Cultural Center of Rizhao.

In 2006, Rizhao's Dragon and Sui Dances were included in the first batch of Rizhao's "Intangible Cultural Heritage". In 2013, the skills of walking on stilts as well as "removing the Shrimp Skin" (tui xia pi) were selected for inclusion in the second batch. In June 2018, the issue named "Rizhao city—Sort out, Develop and Inherit the Stilts Dance" became the key topic in Shandong Province's art science field.

Challenges. Endowed with such a rich cultural heritage, considerable scope exists to combine heritage protection with developmental sustainability through tourist promotion in the footsteps of other similarly endowed sites. However, efforts to emulate successes immediately raises major challenges for Rizhao. The first is financial support. With many assets to support in the area around Rizhao, government funding is not sufficient to preserve the Festival in its original form.

The lack of funding affects the sustainability of the Dances because the meagre allowances for performers are already unable to maintain interest among the small pool of organizers and performers, who, by tradition, are all amateurs, and limits funds for research on the dances, which could lead to improvements in the organization and substance of the dances, and renders even the renewal of costumes and props for the performance problematic. Achieving financial sustainability is therefore paramount among all issues of heritage preservation.

Attempts to deal with these challenges have their own side-effects. For instance, the Rizhao city government, in organizing many activities to promote the Festival, had inadvertently changed the form and substance of the Festival, limiting the freedom of organizers and artisans to shape the Fishermen's Festival as they see fit and in keeping with tradition. This reflects the first area of potential conflict of interest between key stakeholders of the Festival.

Efforts to draw tourists by professionalizing performances, as have occurred in Lijiang, can also lead to dilution of traditional aspects of the heritage, emphasizing the parts of performances deemed to have greater tourist appeal. Reliance on professional performers also increases the distance between 
performances with tourist appeal and traditional performances. An increase in the number of tourists to Rizhao can also bring environmental pollution and adversely impact the city's green credentials [84].

There were other areas of conflict. To accommodate more visitors and a larger audience, the venue of these dances has been moved to Rizhao City rather than being performed in the villages which were their original venues. Catering to the tourist trade inevitably brings commercialization and professionalization, with the likelihood of the loss of traditional performance arts. Commercial success has therefore to be balanced against damage to cultural heritage.

Fortunately, innovative approaches now exist to bolster financing and other dimensions of heritage preservation that have yet to be attempted for Rizhao. To meet financing needs, social enterprises are being increasingly called upon to play the role that traditional channels have failed to play. Innovative efforts at revitalizing interest among stakeholders, especially organizers, performers and their kin, but also among audiences, through targeted approaches that separate ritual from entertainment, campaigns to stoke national pride, creating awareness through education, and rewarding artistes through conferring titles like "national treasures" have met with success elsewhere [18]. A new approach to tourism that takes advantage of "destination's specificities ... that involves prioritizing and targeting niche tourism" has also been proposed [85] (p.274).

\subsection{Comparing Lijiang with Rizhao}

While Lijiang and Rizhao possess many commonalities, they also stand out as contrasting models of intangible cultural heritage protection. Both are documented in Table 3. Among their commonalities, they both have traditional dances to showcase- the Naxi Ethnic Dance (Dongba Dance) in Lijiang and the Fishermen's Festival Dances in Rizhao. In both locations, the festivities reflect strong cultural identities. They host a multitude of cultural heritage assets. Many of these assets, especially the dances, are of great antiquity, and they can showcase their cultural assets in impressive geographic settings. The performances are centrally located—the Impression Lijiang at the foothills of Yulong Mountain and the Fishermen's Festival dances in Rizhao city.

Table 3. Similarities between Lijiang and Rizhao in Cultural Tourism.

\begin{tabular}{ccc}
\hline \multirow{2}{*}{ Similarities } & \multicolumn{2}{c}{ Contrasts } \\
\cline { 2 - 3 } & Lijiang & Rizhao \\
\hline $\begin{array}{c}\text { Rich in cultural assets } \\
\text { Strong awareness of cultural } \\
\text { identity }\end{array}$ & Emphasizes performance & Emphasizes heritage, authenticity \\
\hline $\begin{array}{c}\text { Advantageous geographical } \\
\text { location }\end{array}$ & $\begin{array}{c}\text { Secondary benefits to other rural } \\
\text { residents }\end{array}$ & No secondary benefits \\
\hline $\begin{array}{c}\text { Historical antiquity } \\
\text { Strong cultural identity }\end{array}$ & Attracted urban investors, return \\
migrants & Barely able to retain local talent \\
\hline & Private sector has major role & State-driven \\
\hline
\end{tabular}

These similarities are, however, overshadowed by their many differences. First and foremost is the manner of tourist promotion and heritage preservation. The Lijiang model has been much more successful, not only in ensuring financial sustainability but also in generating secondary benefits for related sectors like hospitality and for the rural community around Lijiang. The scale of Lijiang's initiative has promoted rural innovation, reflected in creative ideas in organizing cooperatives. Meanwhile, the high incomes generated have attracted younger rural-urban migrants to return to their villages. Simultaneously, urban talents and residents have been keen to invest and stay, thus securing the long-term sustainability of the Lijiang project, and helping to achieve the rural rejuvenation 
objectives of people-oriented development through intangible cultural heritage preservation. Still striving to ensure sufficient funding, organizers of the Fishermen's Festival in Rizhao have had much less to show for their efforts, having to make adjustments to attract tourist traffic just to stay afloat. Without adequate funding, the fishermen's Festival has, with the exception of tourism income, the quantum of which is unknown, bestowed limited benefits to the fishermen community and the residents of Rizhao.

This disparity does not mean that Rizhao does not have the potential to emulate Lijiang's achievements. It does mean that Rizhao is still at an early stage in planning for heritage preservation, although not necessarily in applying the Lijiang model in terms of deploying human resources and capital inputs. This disparity is also a reflection of the different priorities in the fiscal resources have been deployed. Lijiang has received substantial support from the Yunnan provincial government; the provincial government of Shandong, certainly no less wealthy than Yunnan province, has elected to allocate its fiscal resources to a range of tourism projects, leaving funding for the Fishermen's Festival and its dances in the hands of the Rizhao city government.

Despite Rizhao's apparent disadvantages, it can boast certain advantages. Whereas Lijiang's cultural heritage is embedded in an artistically created, spectacular but artificial extravaganza, Rizhao's remains largely true to its historical roots in the staging of performances. The formats of the dances are also substantively different. Whatever claims Impression Lijiang may have of complying with tradition, there is little doubt that a major objective of the performance is entertainment. The Fishermen's Festival dances have a much stronger claim to traditional authenticity, being still performed by amateurs to whom the rewards are uncertain. However, this adherence to tradition may see the art form gradually disappear for lack of interest. In this respect, Lijiang may have lessons for Rizhao, one of the most important being the corporatization of the dances to ensure not only professional management but also the participation of major stakeholders. As a final area of comparison, both Lijiang and Rizhao appear conscious of the need for environmental sustainability and the threat that heightened tourism poses. This is particularly the case with Rizhao, with its reputation as one of the greenest cities in China.

\section{Conclusions}

There can be no question about the constructive role of cultural heritage, both tangible and intangible, in society in general and in development in particular. Given this role, efforts should be made to capture its benefits. However, this role is not without costs. These costs are associated with the possible increase in pollution that heightened tourist traffic will bring. The possible costs associated with departures from authenticity are also included. A developmental role for heritage preservation must seek to manage such costs while maximizing benefits.

With its considerable inventory of cultural assets, both tangible and intangible, China has to manage its costs to capture the benefits. As shown in this paper, the cost-benefit calculus is even more significant, since it is part of China's rural development. The lessons learned from this development experience, and from two case studies, clearly demonstrate the vital roles of key stakeholders-the state, at central, provincial and local government levels, as well as local communities-in capturing heritage benefits. In as much as the state has the resources, both financial and institutional, to promote heritage tourism, success also depends crucially on the community's identification with, and sense of ownership of, the cultural assets. As the Lijiang example shows, both can galvanize a community towards adopting measures to ensure sustainability.

The case studies also show that trade-offs exist between tourism promotion and heritage preservation. Achieving a measure of success in both objectives requires balancing-between heritage preservation and long-term sustainability, and between state control and community ownership. Besides these case studies, different approaches under the rubric of rural rejuvenation may well produce innovative models that can be prototypes for tourism that also ensures heritage preservation. At the risk of generalization from the case studies, the key to successfully combining sustainability with heritage preservation likely lies with the state's leveraging bottom-up strategies that demonstrate 
"thorough understanding of local specificities ... (and) take into account the characteristics and long-term needs of local residents and how they inhabit their local environment" [10] (p. 37).

Author Contributions: Data is collected by X.S. and Q.W. mainly. The paper is framed by K.-C.C. The draft is prepared by K.-C.C. and Q.W. The revision is done by K.-C.C. and Y.L. All authors have read and agreed to the published version of the manuscript.

Funding: This work was supported by the Doctoral Foundation of Shandong Technology and Business University (BS201928), National Natural Science Foundation of China (Grant Nos. 41571166 and 41971220).

Conflicts of Interest: There is no interest conflict.

\section{References}

1. Wilkinson, S.; Remey, H. "Heritage Building Preservation vs. Sustainability: Conflict Isn't Inevitable", The Conversation 29 November 2017. Available online: https://theconversation.com/heritage-buildingpreservation-vs-sustainability-conflict-isnt-inevitable-83973 (accessed on 26 June 2019).

2. Basu, P.; Modest, W. (Eds.) Museums, Heritage and International Development; Routledge: London, UK, 2014.

3. Tadros, M. "Should Development Concern Itself with Cultural Heritage Preservation?" Institute of Development Studies, 14 February 2018. Available online: https://www.ids.ac.uk/opinions/shoulddevelopment-concern-itself-with-cultural-heritage-preservation/ (accessed on 24 June 2019).

4. Avrami, E. Making Historic Preservation Sustainable. J. Am. Plan. Assoc. 2016, 82, 104-112. [CrossRef]

5. Bortolotto, C. From objects to processes: UNESCO's 'intangible cultural heritage'. J. Mus. Ethnogr. 2007, 19, 21-33.

6. Safford, L.B. Cultural Heritage Preservation in Modern China: Problems, Perspectives, and Potentials. ASIANetwork Exch. A J. Asian Stud. Lib. Arts 2014, 21, 3. [CrossRef]

7. World Commission on Environment and Development (WCED). Our Common Future: From One Earth to One World; Oxford University Press: Oxford, UK, 1987.

8. Zhu, G. China's architectural heritage conservation movement. Front. Archit. Res. 2012, 1, 10-22. [CrossRef]

9. Wang, Y. The conservation of intangible cultural heritage in historic areas. In Proceedings of the 16th ICOMOS General Assembly and International Symposium: 'Finding the Spirit of Place-Between the Tangible and the Intangible', Quebec, QC, Canada, 29 September-4 October 2008.

10. Iossifova, D. China: Toward an integrated approach to cultural heritage preservation and economic development. CityCity Mag. 2014, 2014, 34-37.

11. Rees, H. Intangible Cultural Heritage Protection in China, Asia Dialogue 25 July 2017. Available online: https: //theasiadialogue.com/2017/07/25/intangible-cultural-heritage-protection-in-china/ (accessed on 25 July 2017).

12. Tadros, M. "Cultural Heritage Preservation: Development's Enabling Role?" Institute of Development Studies, 23 February 2018. Available online: https://www.ids.ac.uk/opinions/cultural-heritage-preservationdevelopments-enabling-role/ (accessed on 23 June 2019).

13. Rypkema, D. Culture, Historic Preservation and Economic Development in the 21st Century. In Proceedings of the Leadership Conference on Conservancy and Development, Yunnan Province, China, 26 September 1999; Available online: http://www.columbia.edu/cu/china/DRPAP.html (accessed on 25 June 2019).

14. Roe, E. Narrative Policy Analysis; Duke University Press: Durham, UK, 1994.

15. Yang, Y.; Liu, Y.-S.; Li, Y.; Du, G. Quantifying spatio-temporal patterns of urban expansion in Beijing during 1985-2013 with rural-urban development transformation. Land Use Policy 2018, 74, 220-230. [CrossRef]

16. Plaza, A.B. The Trade-off between Economic Development, Heritage Preservation in Urban Southeast Asia, 26 April 2016. Available online: https://blogs.adb.org/blog/trade-between-economic-development-heritagepreservation-urban-southeast-asia (accessed on 25 June 2019).

17. Xue, L.; Kerstetter, D.; Hunt, C.A. Tourism development and changing rural identity in China. Ann. Tour. Res. 2017, 66, 170-182. [CrossRef]

18. Takako, I. Preservation of traditional art: The case of the nooraa performance in Southern Thailand. Wacana Seni J. Arts Discourse 2008, 7, 1-22.

19. Mualam, N.; Alterman, R. Architecture is not everything: A multi-faceted conceptual framework for evaluating heritage protection policies and disputes. Int. J. Cult. Policy 2018, 26, 291-311. [CrossRef] 
20. Cooper, D.J.; Musschetto, V. Reconciling Preservation and Sustainability, 3 February. Available online: https://www.architectmagazine.com/technology/reconciling-preservation-and-sustainability_o (accessed on 26 June 2019).

21. You, Z. Shifting Actors and Power Relations: Contentious Local Responses to the Safeguarding of Intangible Cultural Heritage in Contemporary China. J. Folk. Res. Int. J. Folk. Ethnomusicol. 2015, 52, 253. [CrossRef]

22. McKercher, B.; Ho, P.S.; Du Cros, H. Relationship between tourism and cultural heritage management: Evidence from Hong Kong. Tour. Manag. 2005, 26, 539-548. [CrossRef]

23. Chan, W.; Ma, S. Heritage preservation and sustainability of China's development. Sustain. Dev. 2004, 12, 15-31.

24. Wang, Y. The Conservation of Intangible Cultural Heritage in Historic Areas. Available online: https://www.researchgate.net/publication/277990262_The_conservation_of_intangible_cultural_ heritage_in_historic_areas (accessed on 11 June 2008).

25. Shen, C.; Chen, H.; Messenger, P.M.; Smith, G.S. Cultural Heritage Management in China. Cult. Herit. Manag. 2010, 5, 70-81. [CrossRef]

26. Huo, Z. Legal prospection of cultural heritage in China: A challenge to keep history alive. Int. J. Cult. Policy 2015, 22, 497-515. [CrossRef]

27. Petronela, T. The Importance of the Intangible Cultural Heritage in the Economy. Procedia Econ. Financ. 2016, 39, 731-736. [CrossRef]

28. Tong, M. "Cultural Heritage Conservation in China-Practices and Achievements in the Twenty-First Century", The Getty Conservation Institute, 26 September 2016. Available online: https://www. getty.edu/conservation/publications_resources/newsletters/31_1/practices_achievements.html (accessed on 11 June 2019).

29. Xinhuanet “China Forms Intangible Cultural Heritage Protection Network”, 31 May 2019. Available online: http://www.xinhuanet.com/english/2019-05/31/c_138105950.htm (accessed on 11 August 2019).

30. Zhuang, P. “China Plans Law to Make Reviving Rural Areas Apriority in Modernization Push", South China Morning Post, 10 March 2019. Available online: https://www.scmp.com/news/china/politics/article/2189358/ china-plans-law-make-reviving-rural-areas-priority-modernisation (accessed on 3 July 2019).

31. Lewis, W.A. Economic Development with Unlimited Supplies of Labour. Manch. Sch. 1954, 22, $139-191$. [CrossRef]

32. Chen, C.; LeGates, R.; Fang, C. From coordinated to integrated urban and rural development in China's megacity regions. J. Urban Aff. 2018, 41, 150-169. [CrossRef]

33. Chen, C.; LeGates, R.; Zhao, M.; Fang, C. The changing rural-urban divide in China's megacities. Cities 2018, 81, 81-90. [CrossRef]

34. Zhao, S.X.B.; Wong, K.K. The sustainability dilemma of China's township and village enterprises: An analysis from spatial and functional perspectives. J. Rural. Stud. 2002, 18, 257-273. [CrossRef]

35. Zhou, T.; Jiang, G.; Zhang, R.; Zheng, Q.; Ma, W.; Zhao, Q.; Li, Y. Addressing the rural in situ urbanization (RISU) in the Beijing-Tianjin-Hebei region: Spatio-temporal pattern and driving mechanism. Cities 2018, 75, 59-71. [CrossRef]

36. Peng, J.; Ma, J.; Liu, Q.; Liu, Y.; Hu, Y.; Li, Y.; Yue, Y. Spatial-temporal change of land surface temperature across 285 cities in China: An urban-rural contrast perspective. Sci. Total. Environ. 2018, 635, 487-497. [CrossRef]

37. Wang, Q.; Zhang, M.; Cheong, K.C. Stakeholder perspectives of China's land consolidation program: A case study of Dongnan Village, Shandong Province. Habitat Int. 2014, 43, 172-180. [CrossRef]

38. Fang, C.; Yu, D. China's New Urbanization Developmental Paths; Blueprints and Patterns; Springer Geography: Berlin/Heidelberg, Germany, 2016.

39. Zeng, C.; Song, Y.; He, Q.; Liu, Y. Urban-rural income change: Influences of landscape pattern and administrative spatial spillover effect. Appl. Geogr. 2018, 97, 248-262. [CrossRef]

40. Tian, N.; Zhao, B. Spatio-temporal evolutionary characteristics of county-level in China since the reform and opening-up. Resour. Dev. Mark. 2019, 35, 359-365.

41. Long, H.; Li, Y.; Liu, Y.-S.; Woods, M.; Zou, J. Accelerated restructuring in rural China fueled by 'increasing vs. decreasing balance' land-use policy for dealing with hollowed villages. Land Use Policy 2012, 29, 11-22. [CrossRef] 
42. Qu, Y.; Long, H. The economic and environmental effects of land use transitions under rapid urbanization and the implications for land use management. Habitat Int. 2018, 82, 113-121. [CrossRef]

43. Li, Y.; Zhang, H.; Zhang, D.; Abrahams, R. Mediating urban transition through rural tourism. Ann. Tour. Res. 2019, 75, 152-164. [CrossRef]

44. Chen, M.; Liu, W.; Lu, D.; Chen, H.; Ye, C. Progress of China's new-type urbanization construction since 2014: A preliminary assessment. Cities 2018, 78, 180-193. [CrossRef]

45. Cheng, W.; Xu, Y.; Zhou, N.; He, Z.; Zhang, L. How did land titling affect China's rural land rental market? Size, composition and efficiency. Land Use Policy 2019, 82, 609-619. [CrossRef]

46. Chen, M.; Gong, Y.; Lu, D.; Ye, C. Build a people-oriented urbanization: China's new-type urbanization dream and Anhui model. Land Use Policy 2019, 80, 1-9. [CrossRef]

47. Liu, Y.; Fan, P.; Yue, W.; Song, Y. Impacts of land finance on urban sprawl in China: The case of Chongqing. Land Use Policy 2018, 72, 420-432. [CrossRef]

48. Ma, W.; Renwick, A.; Nie, P.; Tang, J.; Cai, R. Off-farm work, smartphone use and household income: Evidence from rural China. China Econ. Rev. 2018, 52, 80-94. [CrossRef]

49. Ma, W.; Zhou, X.; Renwick, A. Impact of off-farm income on household energy expenditures in China: Implications for rural energy transition. Energy Policy 2019, 127, 248-258. [CrossRef]

50. Su, C.; Liu, T.-Y.; Chang, H.; Jiang, X. Is urbanization narrowing the urban-rural income gap? A cross-regional study of China. Habitat Int. 2015, 48, 79-86. [CrossRef]

51. Wang, S.; Tan, S.; Yang, S.; Lin, Q.; Zhang, L. Urban-biased land development policy and the urban-rural income gap: Evidence from Hubei Province, China. Land Use Policy 2019, 87, 104066. [CrossRef]

52. Li, Y.; Yi, L.; Pengcan, F.; Hualou, L. Impacts of land consolidation on rural human-environment system in typical watershed of the Loess Plateau and implications for rural development policy. Land Use Policy 2019, 86, 339-350. [CrossRef]

53. Liu, Y.-S.; Lu, S.; Chen, Y. Spatio-temporal change of urban-rural equalized development patterns in China and its driving factors. J. Rural. Stud. 2013, 32, 320-330. [CrossRef]

54. Qi, W.; Deng, Y.; Fu, B. Rural attraction: The spatial pattern and driving factors of China's rural in-migration. J. Rural. Stud. 2019. [CrossRef]

55. Su, M.M.; Wall, G.; Wang, Y.; Jin, M. Livelihood sustainability in a rural tourism destination-Hetu Town, Anhui Province, China. Tour. Manag. 2019, 71, 272-281. [CrossRef]

56. Yep, R.; Forrest, R. Elevating the peasants into high-rise apartments: The land bill system in Chongqing as a solution for land conflicts in China? J. Rural. Stud. 2016, 47, 474-484. [CrossRef]

57. Song, C.; Liu, Q.; Gu, S.; Wang, Q. The impact of China's urbanization on economic growth and pollutant emissions: An empirical study based on input-output analysis. J. Clean. Prod. 2018, 198, 1289-1301. [CrossRef]

58. Han, S.; Lin, W. Transforming rural housing land to farmland in Chongqing, China: The land coupon approach and farmers' complaints. Land Use Policy 2019, 83, 370-378. [CrossRef]

59. Chen, H.; Wang, X. Exploring the relationship between rural village characteristics and Chinese return migrants' participation in farming: Path dependence in rural employment. Cities 2019, 88, 136-143. [CrossRef]

60. Deininger, K.; Jin, S.; Xia, F.; Huang, J. Moving Off the Farm: Land Institutions to Facilitate Structural Transformation and Agricultural Productivity Growth in China. World Dev. 2014, 59, 505-520. [CrossRef]

61. Chen, C.; Gao, J.; Chen, J. Behavioral logics of local actors enrolled in the restructuring of rural China: A case study of Haoqiao Village in northern Jiangsu. J. Rural. Stud. 2019. [CrossRef]

62. Yan, J.; Chen, H.; Xia, F. Toward improved land elements for urban-rural integration: A cell concept of an urban-rural mixed community. Habitat Int. 2018, 77, 110-120. [CrossRef]

63. Liu, W.; Dunford, M.; Song, Z.; Chen, M. Urban-rural integration drives regional economic growth in Chongqing, Western China. Area Dev. Policy 2016, 1, 132-154. [CrossRef]

64. Liu, Y.-S.; Liu, J.-L.; Zhou, Y. Spatio-temporal patterns of rural poverty in China and targeted poverty alleviation strategies. J. Rural. Stud. 2017, 52, 66-75. [CrossRef]

65. Tian, Q.; Guo, L.; Zheng, L. Urbanization and rural livelihoods: A case study from Jiangxi Province, China. J. Rural. Stud. 2016, 47, 577-587. [CrossRef]

66. Chen, J.-C.; Zinda, J.A.; Yeh, E. Recasting the rural: State, society and environment in contemporary China. Geoforum 2017, 78, 83-88. [CrossRef] 
67. Xu, Y.; Huang, X.; Bao, H.X.H.; Ju, X.; Zhong, T.; Chen, Z.; Zhou, Y. Rural land rights reform and agro-environmental sustainability: Empirical evidence from China. Land Use Policy 2018, 74, $73-87$. [CrossRef]

68. Zhang, L.; Cao, Y.; Bai, Y. The impact of the land certificated program on the farmland rental market in rural China. J. Rural. Stud. 2019. [CrossRef]

69. Hu, S.; Zhu, H.; Sun, Z. Rural issues under China's rapid urbanization. Hebei Acad. J. 2013, 33, 94-96.

70. Li, Y.; Jia, L.; Wu, W.; Yan, J.; Liu, Y.-S. Urbanization for rural sustainability-Rethinking China's urbanization strategy. J. Clean. Prod. 2018, 178, 580-586. [CrossRef]

71. Gao, J.; Wu, B. Revitalizing traditional villages through rural tourism: A case study of Yuanjia Village, Shaanxi Province, China. Tour. Manag. 2017, 63, 223-233. [CrossRef]

72. Shen, S.; Wang, H.; Quan, Q.; Xu, J. Rurality and rural tourism development in China. Tour. Manag. Perspect. 2019, 30, 98-106. [CrossRef]

73. Hu, X.; Bao, J. Evolution of rural tourism landscape character network: The case of Jiangxiang village. Geogr. Res. 2016, 38, 1561-1575.

74. Rees, H. Intangible Cultural Heritage Protection in China, Asia Dialogue 25 July 2017. Available online: https://theasiadialogue.com/2017/07/page/3/ (accessed on 1 July 2019).

75. Duncan, E.M. Tourism and Cultural Heritage Preservation. SSRN Electron. J. 2009. [CrossRef]

76. Irandu, E.M. The role of tourism in the conservation of cultural heritage in Kenya. Asia Pac. J. Tour. Res. 2004, 9, 133-150. [CrossRef]

77. Lussetyowati, T. Preservation and conservation through cultural heritage tourism. Case study: Musi riverside Palembang. Procedia Soc. Behav. Sci. 2015, 184, 401-406. [CrossRef]

78. Huang, X. Research into the business patterns of tourism performing project-take The Impression of Lijiang and The Legend of Romance as an example. J. Hunan Inst. Eng. 2013, 23, $22-27$.

79. $\mathrm{Bu}, \mathrm{W} . ;$ -a case study of national and ecological tourism in Hai Village of Lijiang. J. Qujing Norm. Univ. 2011, 30, 69-74.

80. Liu, Y. New Rural Construction Problems and Countermeasures of Weifang Coastal Areas. Master's Thesis, Ocean University of China, Qingdao, China, 2013.

81. Ye, Z. On the shortage of migrant workers in southeastern coastal cities of China based on the labor supply status of Henan Province. J. Xinyang Coll. Agric. For. 2015, 25, 73-76.

82. Ding, N.; Li, G.; Yuan, Y. Rural community governance mode transation under New Urbanization progress. J. Reg. Econ. 2015, 6, 56-61.

83. Cao, P. The difficulty and confusion in the protection of traditional buildings under the background of New Urbanization. J. Shanxi Archit. 2018, 44, 21-22.

84. Blello, D. Against enormous odds, a Chinese official is Trying to Green up His City, Huffington Post, 24 March 2014. Available online: https://www.huffpost.com/ entry/chinese-city-climate-change_n_58407c2be4b017f37fe38018?guccounter=1\&guce_referrer= aHR0cHM6Ly93d3cuZ29vZ2xlLmNvbS8\&guce_referrer_sig=AQAAAFznf5QdtdSmsD5HSMbsfZLZ0ci_EXk-vQ52ooL4JStVRbWLBtzdxP-plZQwp0zUc_Met0dxSlyqH7ixH0HtkUTghxx2dDtJU_ cjCXehOC2gUaHqszuAer63FIVIcvXUaKKIFu3FQy-pmzrutAEuxZbK3W0J7cR9ul-LAkaXKAu (accessed on 21 November 2018).

85. Sotiriadis, M.; Vrontis, D.; Tsoukatos, E. Pairing intangible cultural heritage with tourism: The case of Mediterranean diet. EuroMed J. Bus. 2017, 12, 269-284. [CrossRef]

(C) 2020 by the authors. Licensee MDPI, Basel, Switzerland. This article is an open access article distributed under the terms and conditions of the Creative Commons Attribution (CC BY) license (http://creativecommons.org/licenses/by/4.0/). 